Magnetite (titanomagnetite) is present in irregular, often rounded grains, but some crystals show isometric sections. A highly refracting border (leucoxene?) surrounds some of the grains, indicating the presence of titanium. Scott Elliot noted the occurrence "in the hills behind Sierra Leone" of a titaniferous iron-ore yielding 52 per cent of metallic iron and 14 per cent of $\mathrm{Ti}_{2}$. Gürich, too, saw in a private collection of minerals in Freetown lumps of magnetite as large as the fist. I venture to conclude that this ore-body occurs as a segregation within the norite; indeed, the recognition of the petrographic character of the rock would lead one to anticipate the existence of such segregations. These indications ought to be followed up, as they might lead to the discovery of important oredeposits. The matter is one for the attention of the Imperial Mineral Resources Bureau.

Estimates of the percentage composition of these rocks yielded the following results in the case of $(A)$, a specimen of what $I$ have called the average rock, and (B) the aplitic facies:-

A.

B.

\begin{tabular}{|c|c|c|c|c|}
\hline & Vol. \%. & Weight \%. & Vol. \%. & Weight $\%$. \\
\hline Plagioclase & 74 & 69 & 41 & 35 \\
\hline Olivine . & 14 & 16 & 0 & 0 \\
\hline Diallage & 9 & & $\int 0$ & 0 \\
\hline Hypersthene $f$ & - & 10 & 155 & 59 \\
\hline Magnetite & $2 \cdot 3$ & 4 & 4 & 6 \\
\hline
\end{tabular}

The order in which the minerals crystallized is as follows: labradorite, olivine, diallage, hรpersthene; magnetite uncertain. In brief, the fine-grained rock is a melunocratic norite $\left(\mathrm{m}_{6}-\right.$ micronorite), while the coarser varieties are leucocratic olivine-norites $\left(l_{6}-\right.$ to $l_{9}$ - subnorite). I invite attention here to a change which ought to be made in the subdivision of the gabbroitic rocks; namely, that in deciding whether a rock is to be attached to gabbro or to norite the olivine should be reckoned along with the rhombic pyroxenes, since the latter minerals arise by the addition of silica to olivine. Thus all troctolites and "olivine-gabbros" (including those above described) in which the sum of olivine plus rhombic pyroxenes exceeds that of the monoclinic pyroxenes should be regarded as norite (subnorite), not as gabbro.

\title{
NOTIOFS OF MEIMOIRS.
}

On the Geological Structure of the Forest of Dran. ${ }^{1}$ By T. Franklin Siblx, D.Sc., F.G.S., Professor of Geology in the University College of South Wales and Monmouthshire, Cardiff.

(A paper read before the Forest of Dean Branch of the National Association of Colliery Managers on October 25, 1917.)

TN $1894 \mathrm{Dr}$. R. Kidston correlated the Coal Measures of the Forest 1 of Dean with the true Upper Coal Measures." In 1910 Dr. T. T. Groom, reasoning from this correlation, pointed out that "unless the

1 Reprinted (by permission), with some emendations by the author, from the Colliery Guardian, vol. cxiv, No. 2966, November 2, 1917, pp. 839-40.

2 Proc. Roy. Phys. Soc. Edin., vol. xii, p. 222, 1894. 


\section{Notices of Memoirs-Professor T. Franklin Sibly-}

measures that have not been detected [the true Lower and Middle Coal Measures] are exceedingly thin, or are represented, by the upper part of the Millstone Grit, there must be an unconformity at the base of the Coal Measures".

The late Dr. A. Vaughan had proved the Lower Carboniferous age of the lowest beds of the Millstone Grit near Mitcheldean. ${ }^{2}$ In 1912 Dr. E. A. Newell Arber, whose detailed study of the fossil plants in the local Coal Measures confirmed Dr. Kidston's correlation, wrote as follows: "Reviewing the present evidence $I$ am inclined to think that it will eventually prove that an unconformity exists a short distance below the Lower: Trenchard Coal perhaps a little above the Sandstone vein of Iron Ore. . . . True Millstone Grits, Lower, Middle, and Transition Coal Measures appear to be absent in the Forest of Dean, so that the unconformity in question is of considerable importance." 3

'The present author's independent investigations led him in 1912 to the conclusion that an unconformity at the base of the Coal Measures is an important structural feature in the Forest of Dean. In a short paper on the Carboniferons succession " he described the Lower Carboniferous sequence near Mitcheldean, proposed the name Drybrook Sandstone for the "Millstone Grit" of the district, and demonstrated the reality of the intra-Carboniferous unconformity by describing the persistent overstep of the Coal Measures across the Drybrook Sandstone and Carboniferons Limestone, as well as by other evidence.

The author has been assisted in his later researches in the district by a grant from the Government Grant Committee of the Royal Society. He is permitted by the Director of the Geological Survey of Great Britain to make use of information gained in the course of his present investigation, as an officer of the Geological Survey, of iron-ores in the Forest of Dean.

It is well established on palæontological evidence that the Carboniferous Limestone of the Forest of Dean represents, approximately, the lower half only of the same formation as seen in the Avon Gorge at Bristol. The zones of the Carboniferous Limestone Series in the Avon Gorge, recognized by the late Dr. Vaughan, are denoted, in ascending sequence, by the symbols $K, Z, C, S, D$. The highest member of the Carboniferous Limestone on the northeastern borders of the Forest of Dean, the Whitehead Limestone, represents the topmost part of $C$ (Syringothyris zone) and possibly the lowest part of S (Seminula zone). The Whitehead Limestone, which rarely exceeds 30 feet in thickness, gives place on the sonthwestern border of the Forest to a series of dolomite-mudstones, black and grey crystalline dolomites, and clars with dolomite nodules, of much greater thickness; but this series does not encroach much on the Seminula zone.

1 Geology in the Field, Jubilee Volume of the Geologists' Association, 1910, p. 731.

Q.J.G.S., vol. 1xi, p. 252, 1905.

3 Phil. Trans. Roy. Soc., vol. ceii, B, pp. 270, 277, 1912.

${ }^{4}$ Geol. MAG., N.S., Dec. V, Vol. IX, pp. 417-22, 1912. 
The upper portion of the Carboniferous Limestone of areas to the south is represented in the so-called Millstone Grit of the Forest of Deun. This Millstone Grit, which succeeds the Carboniferous Limestone quite conformably, is mainly, if not entirely, a formation of Lower Carboniferous age. The name Drybrook Sandstone was applied to it in 1912 .

Thick bands of limestone and dolomite appear in the Drybrook Sandstone on the south-western margin of the coal-field. Near Milkwull oolitic limestones in the lower part of the formation have yielded Seminula ficoides, Cyrtina carbonaria, and other fossils of the main Seminula zone $\left(\mathrm{S}_{2}\right)$. Cyrtina carbonaria has also been observed in corresponding beds of dolomite in the Parkhill adit (Fryer's Level). The lower portion of the Drybrook Sandstone may, therefore, be correlated definitely with the main Seminula zone of the Carboniferous Limestone. Unquestionably, the Drybrook Sandstone passes laterally into limestones as we proceed from the north-eastern margin of the Forest of Dean southwards to Chepstow and Bristol.

Concurrently with the development of limestones the arenaceous beds, which compose the bulk of the Drybrook Sandstone even on the south-western margin of the coal-field, become finer in grain when followed south-westwards. For example, seams of quartzconglomerate are conspicuous in the Drybrook Sandstone of the Mitcheldean district, but these have dwindled to insignificance in the neighbourhood of Bream. Bands of shale and fine-grained sandstone, containing shreds of coal, are found in the upper part of the Drybrook Sandstone in the Parkhill adit.

Owing to overstep by the unconformable Coal Measures the Drybrook Sandstone is wholly concealed both on the south-east between Lydney Park and Staple Edge Wood, where the Carboniferous Limestone also is concealed, and on the north between Drybrook and Lydbrook Valley. From the same cause the apparent thickness of the Drybrook Sandstone varies greatly, and in no regular manner, along its outcrop. The thickness is at least 650 feet in the Soudley Valley between the Shakemantle Pit and Staple Edge Halt, where the upper beds are well exposed on the railway.

The Coal Measures of the Forest of Dean lie unconformably, and sometimes with great discordance of dip, upon an eroded floor formed by the Drybrook Sandstone, the Carboniferous Limestone, and on the south-eastern margin of the coal-field, the Old Red Sandstone.

This important unconformity is due to an intra-Carboniferous episode of crust-movement, folding, and denudation which followed the deposition of the Drybrook Sandstone, but preceded the formation of the existing Coal Measures of the Forest. The latter were deposited on the denuded edges of the older strata. An altogether later movement involved the Coal Measures, gare them their present basin-like arrangement, and served also to accentuate the folding previously imposed upon the older rocks.

The intra-Carboniferous disturbance responsible for the unconformity necessarily involved the Silurian and the Old Red Sandstone, together with the Lower Carboniferous strata. It produced the 
main uplift of the May Hill anticline lying immediately east of the Forest of Dean. North-and-south folding predominated, but was accompanied by some east-and-west folding. The result was a basin, markedly unsymmetrical in structure, on the site of the present coal-field. Along what is now the eastern edge of the coal-field the Lower Carboniferous strata were involved in the western limb of the May Hill anticline, and acquired a steep dip westwards, the larger part of the very steep dip that they possess to-day. Westwards across the site of the present coal-field, away from the May Hill axis, the intensity of folding diminished very rapidly, and on the western side of the basin the inward dip of the strata was very slight. Consequently, the beds of the Coal Measures are nearly, but not exactly, accordant with the underlying strata on the western side of the present coal-basin, but markedly discordant with them on the eastern side. But, slight though the discordance may be on the western side, the behaviour of the outcrops supplies convincing evidence of unconformity all around the coal-field. The base of the Coal Measures pays no regard to the strike of the Lower Carboniferous beds, but everywhere passes to and fro, slowly or rapidly, across their outcrops.

Two interesting and significant features are (1) the development of conglomerates at. the base of the Coal Measures, and (2) the concealment of the Trenchard Coal and the measures beneath it by the overlap of the overlying measures, on the south-eastern border of the coal-field. These may be described in connexion with the unconformable overstep of the Coal Measures.

The lowest beds of the Coal Measures, those underlying the Trenchard Coal (Upper Trenchard Coal in some parts of the coalfield), were termed 'Trenchard Measures by the late H. D. Hoskold. ${ }^{1}$ The Trenchard Measures, although variable in character, usually consist largely of yellow grits, in part fine-grained, compact, and well-bedded, in part coarse-grained, friable, and imperfectly stratified. The intercalated clays are sometimes mottled in purple and yellow. A characteristic feature of these grits, particularly in the coarse-grained and conglomeratic varieties, is the abundance of an indurated, white or yellow clay cementing the grains. On the northern and north-eastern borders of the coal-field these grits of the Trenchard Measures often become very coarse-grained and pebbly at their base, and bands packed with quartz pebbles or quartzite pebbles constitute well-defined basal Coal Measure conglomerates.

On the northern edge of the coal-field, between Drybrook and the Lydbrook Valley, the base of the Coal Measures trunsgresses the older strata rather sharply, the Drybrook Sandstone and the upper beds of the Carboniferous Limestone are concealed, and the grits of the Trenchard Measures rest directly upon Carboniferous Limestone. A quarry 1,100 yards east of Ruardean Church shows masses of coarse, pebbly grit resting upon, and in places "piped" down into, the dolomites of the Carboniferous limestone. The former extension of Coal Measures northwards and westwards across the denuded

1 "Geological Notice upon the Forest of Dean": Proc. Cotteswold Nat. Field Club, vol. x, pp. 123-77, 1892. 
edges of the underlying strata is proved by outliers of 'Trenchard Measures. In the large outlier of Howle Hill, represented as Millstone Grit on the Geological Surver map (sheets $43 \mathrm{~S}$. W. and 43.S.E., Old Series), Trenchard Measures rest directly upon the Lower Limestone Shales. A smaller outlier on Courtfield Hill, Welsh Bicknor, not shown on the Survey map, rests upon the Lower Limestone Shales and the base of the Main Limestone.

The railway-cutting immediately north of Drybrook Halt gives a fine section of 'Trenchard Measures resting upon massive sandstones which lie in the lower part of the Drrbrook Sandstone. The basal beds of the Coal Measures is here a remarkable pebble-bed with large, well-rounded pebbles of grey quartzite. This pebble-bed has been traced some distance north of Drybrook, and has been recognized in the Howle Hill outlier.

On the eastern edge of the coal-field from Wigpool Common as far sonth as the Soudley Valley, the 'Trenchard Measures rest upon Drybrook Sandstone. In the Soudley Valley, the railway-cutting south of Staple Edge Halt exposes the unconformable contact of the two formations. Conglomerates forming the base of the Trenchard Measures, and containing fragments of a fine-grained, white sandstone which can be matched in the Drybrook Sandstone of the same cutting, rest upon the Drybrook Sandstone with discordance of dip. The average dip of the Drybrook Sandstone in the cutting is $50^{\circ}$ W.N.W. 'The conglomerates dip slightly north of west at about $25^{\circ}$.

South of the Soudley Valley, overstep carries the base of the Coal Measures southwards, and then eastwards, across fully 650 feet of Drybrook Sandstone and the whole of the Carboniferous Limestone, in the distance of barely 2 miles to the southern side of the Blackpool Valley. The Lower Carboniferous strata maintain a steep north-westerly dip, rising to $65^{\circ}$ in places, as their strike swings gently from S.S.W. to S.W. The Coal Measures maintain a moderate dip a little north of west. The Drybrook Sandstone and the upper beds of the Carboniferous Limestone are transgressed gradually in Staple Edge Wood. The bulk of the Carboniferous Limestone is transgressed very sharply in the Blackpool Valley. On the south side of that valley the base of the Coal Measures continues its rapid overstep eastwards until, just north of Danby Lodge, it crosses the quartz-conglomerates which lie some 400 feet down in the Old Red Sandstone.

In consequence of this sharp overstep the Carboniferous Limestone and the Upper Series of the Old Red Sandstone remain wholly concealed from Danby Lodge to the western side of the Cannop Valley, above Lydney. In and near Stonebury Wood, north of Lydney Park, the quartz-conglomerates of the Old Red and the beds of the Carboniferous Limestone, dipping very steeply westward, reappear from underneath the corer of unconformable Coal Measures. The sharp swing of the Coal Measure base here carries it back rapidly from the Old Red Sandstone on to the Drsbrook Sandstone in Old Park Wood.

The unconformable overstep of the Coal Measures is attended, on 
the south-eastern margin of the coal-field, by conformable overlap. The 'l'renchard Coal and the underlying Trenchard Measures are overlapped by the Pennant Sandstone above them. As a result, the Penuant comes to rest directly and unconformably upon the older, steeply inclined strata, and the Trenchard Mleasures fail to crop over a considerable part of the distance between Staple Edge Wood and the Cannop Valley. This is abundantly clear at Danby Lodge, where the Pennant Sandstone, containing the Coleford High Delf Coal, transgresses the quartz-conglomerates of the Old Red. It is confirmed by the section in an old quarry on the northern side of the Blackpool Valley, which shows the unconformable junction of Pennant Sandstone and Carboniferous Limestone. The sandstones in this quarry dip gently westwards. They show lenticles of clay and a streak of very coarse grit or quartz-conglomerate at their base, and repose upon the worn, hummocky edges of dolomite-beds which dip north-westwards at about $60^{\circ}$.

To sum up, an unconformity at the base of the Coal Measures is a dominant feature in the geological structure of the Forest of Dean. It is evidenced (1) by the overstep of the Coal Measures across the Drybrook Sandstone, the Carboniferous Limestone, and the Old Red Sandstone, (2) by a great difference between the prevailing dip of the older strata and that of the Coal Measures along the eastern margin of the coal-field, and (3) by visible discordance of dip at exposed junctions of the Coal Measures with Drybrook Sandstone and Carboniferous Iimestone respectively. It is attended by (1) the development of basal conglomerates in the Coal Measures, purticularly well seen on the northern border of the coal-field, and (2) local overlap of the Trenchard Measures by the Pennant Sandstone, whereby the former are concealed along part of the south-eastern eoge of the coal-field.

\section{REVIEWS. \\ I.-Grologicat Survey of Great Britain.}

Summary of Progress of the Geological Surver of Great Britain For 1916. 8 ro; pp. iv +56 and 3 figures in text. London, 1917. Price 1s. 6d.

A S was only to be expected, the energies of the Geological Surrey $A$ have been almost entirely diverted into new channels connected with the War. Ordinary field work and detailed mapping are completely suspended, and the remaining staff has devoted itself to the investigation of certain pressing problems connected with the mineral resources of the country. Almost the only exception to this statement is the continuance of the work of examining bore-holes now in progress; this information, if not recorded at once, is necessarily most difficult to recover at a later date. Fire volumes of Special Reports have been published dealing with the occurrence of certain minerals of economic value, and a further volume is in preparation on the subject of refractories; these include sandstones, quartzites, ganister, sands, and fireclays (acid refractories), as well as the basic rock dolomite. These are used for furnace linings and 